\title{
Strengthening Education Character of Primary School Educators
}

\author{
Hardika \\ Department of Non-Formal Education \\ Universitas Negeri Malang \\ Malang, Indonesia \\ hardika.fip@um.ac.id
}

\begin{abstract}
The issue of the quality of educators at the level of primary education has experienced various shocks and paradigm shifts, both in institutional and learning aspects. In this context, primary education has always been an interesting study material because the foundation and pillar of community intellectual development that is closely related to the future of the nation. This paper aims to examine the various problems that hit the world of primary education along with improving the quality of educators through construction strategies, deconstruction and institutional reconstruction and learning. The foundation of the study uses the principle of readiness and psychological maturity, and the values of idealism and pragmatism of education actors
\end{abstract}

Keywords-education character, primary school, educators

\section{INTRODUCTION}

Education is basically intended as a form to improve the quality of human resources. Education that is built early, has a role to shape human resources with dignity, character, and integrity. If a country increases the quality of education, it will indirectly also improve the quality of its human resources. Educators become the foremost element that can determine the progress or precisely the decline of a nation [1].

The existence of competent, professional and capable educators will be a key element in realizing the quality of education. In this case, educators who are none other than teachers must have sufficient competence and expertise so that they can provide good teaching to students. In this context, the urgent issue to be studied is the decline in the educational character possessed by educators in the practice of learning.

The occurrence of the reduction of the character of educating for prospective educators has not become a major study and attention by various groups, both observers, practitioners, and academics [2]. Educational institutions that print prospective educators including primary education institutions do not have the standard of achievement of graduates who are ideal as educators in primary education institutions. The benchmark as an ideal educator to date has never been declared by the education authorities so that in its journey there are never educators who have strong educating characters.

Wardiman Djoyonegoro [3] states there are 3 main requirements that must be considered in education development in order to contribute to improving the quality of human resources. These conditions are: (1) building facilities; (2) quality books; (3) teachers and professional education personnel. based on this, it is known that teachers are one of the factors that greatly influence the development of Indonesian society. Teacher's character influences the quality of learning done and also the quality of students' character because the teacher is also a model in learning.

The results of education cannot be directly known. It takes a certain time or period to find out the results of the education. However, the results of this education will have a strong endurance and impact in society [4]. Education will be able to bring a brighter future. therefore, quality education will bring quality human resources. this quality improvement is demonstrated by the strengthening of character education. in the framework of this improvement, the teacher as an educator must also have a character that can be used as an example for his students.

Awareness of calling to be dedicated, being a teacher who has the character of educating both institutionally and personally is almost neglected. The building, changing and building again must be the spirit of program implementation in strengthening the character of educating prospective future teachers as an effort to produce professional and dedicated teachers with mindful souls in carrying out their duties. No longer academic content, financial incentives are a priority achievement in preparing future educators.

Teachers as the spearhead of education should have 4 main competencies. One of them is personality competence. In this competence, the personality or character of an ideal teacher is absolutely necessary. Teachers should have high responsibility for their profession. This responsibility includes classroom learning activities and education in the school environment.

Teachers as parents in schools should also be examples or examples for their students. Students who have a good attitude, usually also have good character. Good characters include discipline, independence, being able to cooperate, love the homeland, and so on. These various characters should be developed by teachers to their students.

Primary education is the main foundation for the implementation of existing educational and teaching practices. Primary education plays an important role in shaping educated human resources. The purpose of primary education itself is so that students can develop basic skills so that students can develop their lives as members of society, citizens, and religious communities and prepare themselves for further education. But in practice, in Indonesia alone there are still many qualities of teachers who are not qualified enough to teach at the primary education level.

The fundamental problem that is often found in the practice of learning at the primary level is that the quality 
and integrity standards of educators have not been fulfilled that have the capacity and capability to educate at a high level. Present educators are still always struggling about curriculum content and learning outcomes that are quantitative. This can happen because almost every printing institution for primary education educator candidates always uses graduation parameters with a number indicator and graduation speed. Indeed, almost never educational institutions are oriented to the achievement of capacity and capability that emphasizes the personality and integrity of prospective educators themselves [5].

The quality of competent educators will determine the success of the students themselves. Educators or teachers are the spearheads of the education process. In some opinions, the high or low quality of education is determined by the presence of educators. The importance of the role of an educator leads to a large responsibility so that educators can carry out their profession with a high attitude of professionalism. The role of the teacher is very dominant for the formation of personality and ideals that become the dreams of the life of their students in the future. In this situation, the role of the teacher or educator as a role model is needed. The interaction between educators and students is crucial because the existence of both parties will be a bet for determining the quality of education.

The realization of the goal of national education will not succeed if it is not balanced with an increase in the quality of educators. Educators are said to be the front line for the nation's progress. Students will spend more time in school so it is not excessive if it is said that the potential of students is strongly influenced by the school environment, in this case, the role of an educator is definitely needed. A teacher or educator has four core competencies that must be possessed by each teacher, namely pedagogic, professional, personality and social, each of which has components that must be mastered well by every teacher and prospective teacher.

Various issues regarding the quality of teacher educators in primary schools pose a particular challenge for the quality of education in Indonesia. This challenge cannot be negotiated so that the Indonesian people are able to face such intense global competition. Educator quality improvement can be done through education and training, providing opportunities for educators or prospective educators to continue their education at a higher level, providing opportunities for educators to attend seminars, workshops and so on. The series of improvement efforts can make the quality of human resources of educators and prospective educators can increase so that the implications for improving the quality of education.

\section{DISCUSSION}

\section{A. The Role of Primary education as a Pillar of Nation's Intellectual Quality}

Primary education is general education taken for nine years, which is held for six years in elementary school and three years in junior high school. Primary education aims to be able to form students with character, able to live in the community, and able to develop their potential well. Primary education can be said as a "passport" to be able to live in the future.
Primary education for children is conceptualized as formal and non-formal education for each child which generally takes place for children aged around 3 years up to at least 15 years. This primary education is very important to be said as a passport that this primary education is needed by every individual to live and is able to choose what they will do in the future.

The concept of knowledge of students was first built in this level of primary education. If the submission is correct, then students will forever get the right knowledge. However, if the educator has not been able to convey the material correctly the impact is a concept that is wrongly brought by students to adulthood. The success of education will bring students in a better direction so as to advance the nation's civilization. The ability of students related to the ability to think critically, read, write, count and master the basics to learn science and communication skills will be able to develop well at the level of primary education.

Primary education plays an important role for future development for the Indonesian people. Because at the primary education level students will be formed to be what they will be in the future. These characters can be formed since students are still in the primary education stage because at that time students are still easily directed.

\section{B. Educator Quality Improvement}

Chatib [5] divides the level of teacher competence as follows 1) probation period, probation teacher; 2) medium teacher, teacher who has the motto just tell; 3) good teacher, teacher who has a explain motto; 4) an excellent teacher, teacher who has a demonstration motto, and 5) great teacher, teacher who has to inspire motto.

In principle, Case [6]stated that teachers have moral principles attached to their work. thus, teachers as educators should have good morals so that they can be role models for those around them. The moral is certainly related to the character of the teacher. Kunandar [7] stated that the duties and roles of teachers from day to day are getting heavier, along with the development of science and technology. Through the teacher in the school, students are expected to be able to produce students who have high competence and ready to face the challenges of life with full confidence and high confidence.

The teacher has the main competency that is pedagogic. Suhana [5] explains that pedagogic competencies that must be mastered by the teacher are: 1) mastering the characteristics of students from the physical, moral, spiritual, social, cultural, emotional, and intellectual aspects, 2) mastering learning theories and learning principles that educate, 3) develop curriculum related to the subject being taught, 4) organize learning that educates, 5) utilize information and communication technology for the benefit of learning, 6) facilitate the development of potential students to actualize various potentials possessed, 7) communicate effective, empathic, and polite with students, 8) conducting evaluation of process evaluation and learning outcomes, 9) utilizing assessment results for the benefit of learning, and 10) doing reflective actions to improve the quality of learning. Being a teacher means giving good knowledge and education to students. Students certainly want their learning experience to be an unforgettable experience and a memory 
throughout their lives, and can bring them to the achievement of high dreams in the future.

\section{Strengthening Learning Systems in Universities}

Awareness of the ability to develop the character of educating the participants educated at the bachelor level is a delay. This should have been done since they were in high school because the social maturity has already appeared and has an awareness to do actions that can be enjoyed by others around them and aware of the obligation to maintain a value even though they have not been able to account personally [8]. Some things that are less fulfilled and the development of character educating at the level before entering bachelor education become homework that must be overcome by the institution to achieve the goals of a successful learning success.

Wibowo [4] revealed three designs in developing character education, namely: (1) class-based design, which is based on teacher relations as educators and students as learners; (2) school culture-based design, which seeks to build a school culture that is able to shape the character of students with the help of social norms so that certain values are formed and dissipated in students; and (3) communitybased design, which utilizes individual social relationships in building and developing students' character.

Learning in bachelor education certainly has unique characteristics compared to other learning patterns. Universities must be able to produce students who are creative in their work, professional on duty, and scientific in their opinions. Therefore, the learning system in universities must truly be able to produce intellectual products that are creative, independent, innovative in their work and have a strong will to improve and renew their scientific abilities [9]. In the context of higher education as an educational institution for educational personnel, the ability of students must be built towards a more professional, and have integrity as educators.

Overcoming the problem of the quality of educators at the primary school level, several problem-solving strategies are needed. Higher education institutions which are particularly educational university have a large responsibility for the low quality of educators in Indonesia. Universities need to work so that education graduates are able to show good work results when practicing in the field. In this case, the university can analyze the curriculum that it already has, whether the curriculum is still relevant to the development of the current era and evaluate and improve the curriculum that is being implemented.

In the preparation of the university curriculum, the academic community needs to make direct observations on the existing field conditions how the curriculum should be used. Universities need to formulate learning that has the mission of strengthening the ideal character of educating, so that prospective educators are able to design themselves as true learners. True learners certainly have the power to change a person's character from static and fatalist pessimism to a more dynamic, creative and innovative direction.

\section{Renewing Self-Awareness as an Educator}

A teacher when he is a teacher does not just keep learning. Instead, the teacher must be able to innovate in keeping with the times so that the knowledge delivered to students is also in accordance with the times. The teacher is not enough if you only read the latest teaching methods. Rather, the teacher needs to be updated and made aware of his position as an educator. This renewal of self-awareness as an educator becomes very important because of the shift in the mindset of teachers from personal educators to the personalities of workers who must be valued by financial measures.

The era of hedonism has also eroded the idealism of teachers as educators. Environmental demands that are always oriented to the fulfillment of physical needs have also contributed to the reduction of the character of teachers as true educators. The effort to prepare and renew the teacher's awareness as a true educator is not enough to be done only through training activities, seminars, and workshops, but it is necessary to formulate a concept and process that is inherent in the teacher concerned.

Strengthening the character of educating in every educator can be done through institutional strengthening, learning, and selection of appropriate teacher candidates. In this way, certainly, there will be personal educators and learners who have high standards of performance. In this process, it will certainly be found that not everyone will be able to become educators of character because indeed not everyone will be able to position themselves as ideal educators.

\section{E. The Implications}

The ability of the university to respond to the need for educators who have the character of teaching is a challenge that must be answered immediately to meet the needs of loyal and dedicated educators for their profession. Their skills will be honed well if the acceptance of academic abilities and social skills is balanced with the ability to raise awareness of his duties and responsibilities as a teacher. The generation who succeeded in educating their students were those who were able to leave learning for their students with sincerity and teaching teachings that were full of educational awareness not limited to tasks

\section{CONCLUSION}

Strengthening the character of educating for prospective educators at the primary education level must be carried out systematically and pay attention to institutional aspects, learning and characteristics of the prospective educator. There needs to be an ongoing process of education and guidance on capacity and capability and integrity as educators.

Readiness and interest of prospective educators need to be considered well through thorough testing and psychological readiness. Institutional structuring needs to be done by paying attention to the gradual aspects of the division while still prioritizing the connectivity of the mission and the vision of graduates' achievements among levels.

\section{REFERENCES}

[1] P. Cris, "Engaging Student in Learning Process," 2003.

[2] K. . King, Bringing Transformatif Learning to Life. Malabar. Florida: Krieger Publising Company, 2005.

[3] E. Mulyasa, Menjadi Guru Profesional. Bandung: PT Remaja Rosdakarya, 2006. 
[4] A. Wibowo, Pendidikan Karakter: Strategi Membangun Karakter Bangsa Berperadaban. Pustaka Belajar, 2012.

[5] Leonard, "Kompetensi Tenaga Pendidik Di Indonesia: Analisis Dampak Rendahnya Kualitas Sdm Guru Dan Solusi Perbaikannya," vol. 5, no. 3, pp. 192-201, 2015.

[6] Case dkk, Guru Profesional Penyiapan dan Pembimbingan Praktisi Pemikir. Jakarta: PT Indeks, 2009.

[7] Kunandar, Guru Profesional Implementasi KTSP dan Sukses dalam Sertifikasi Guru. Jakarta: PT Raja Grafindo Persada, 2007.
[8] T. Makiguchi, Education for Creative Living. Lowa University Press/Ames, 1989.

[9] S. C. Munandar, Creativity and Education: A Studi of TheRelationshis Between Measures of Creative Thinking and A Number of Educational Variables in Indonesian Primary and Junior Secondary Schools. Ditjen Dikti Depdikbud, 1999. 